\title{
超長大吊橋主塔の初期不整が主ケーブル， ハンガーおよび主塔の安全率設定に与える影響
}

\author{
野上邦栄 ${ }^{1}$ ・長井正嗣 ${ }^{2}$ \\ 1正会員 工榑 東京都立大学助教授 大学院工学研究科土木工学専攻 (

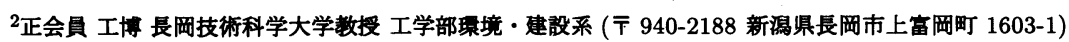

\begin{abstract}
主ケーブル，ハンガー及び主塔の安全率をパラメトリックに変化させた場合の吊橋全体系の終局強度に関す る既往の研究は，これまで初期不整の無い完全系の構造を対象にして解析した成果であったため，大きな軸圧 絡力と曲げモーメントを受ける主塔の初期不整が構造全体系の終局强度に影整することが愁念された．そこで， 本論文では $3000 \mathrm{~m}$ 吊橋主塔に初期不整を考虑した弾塑性有限変位解析を各構成要素の安全率を変化させた断 面に対して実施し，各構成要素の初期降伏および吊橋全体系の終局強度に対してバランスのとれた安全率の組 合わせを検討した．その結果，主塔の初期不整が吊橋全体系の終局強度に与える影鳘は小さいことを明らかに した. したがって，構成要素の安全率の組合わせは初期不整のない場合と同一のものを提案している.
\end{abstract}

Key Words : suspension bridge, tower, safety factor, ultimate strength, elasto-plastic behavior

\section{1. はじめに}

現在，吊橋の主要構成要素である主塔，補剛析，主 ケーブル及びハンガーの設計は, 部材単位の各種照査 事項を満足するように断面設計を行う許容応力度設計 法にしたがっている1),2)。このような現状において, 将 来の海陕横断プロジェクトの実現にはコスト縮堿が大 きな命題となっている. そのための方策の 1 つとして 安全率の見直しが考えられる.これについては,これ までどちらかと言えば, 主ケーブルなどの構成要素の 材料強度に着目した安全率の低減について調查・研究 が進められてきだ),4)。

一方で，超長大橋の終局限界状態を想定した設計で は, 部材の強度限界と吊橋全体系の強度限界を考慮す ることが必要である，そこで，著者らは吊橋全体系の 終局強度の立場からの安全率のあり方について検討し てきた ${ }^{5)}$. その結果, 構造全体系の終局強度に着目し て得られた各粠成要素の安全率は, 現行の安全率に比 べて低減できること，それにともなって鋼重を減らす ことが可能になり工費・工期の縮減に㟢与することを 明らかにした.

しかし，主ケーブル，ハンガー及び主塔の安全率を パラメトリックに変化させた場合の吊橋全体系の終局 強度は, 初期不整の無い完全系の構造を対象にして解 析した成果であり, 特に大きな軸圧縮力と曲げモーメ
ントを受ける主塔の残留応力および初期たわみが構造 全体系の終局強度に影響することが懸念された。

そこで，本論文では吊橋全体系の終局強度特性に主 塔の初期不整がどのように影響するかを明らかにする とともに，その特性から主ケーブル，ハンガー及び主 塔の合理的安全率の組合わせを再検討することを目的 とする. 対象とした吊橋は, 文献 5) の $3000 \mathrm{~m}$ 吊橋で あり, 各構成要素の安全率の変化に対応して試設計し た断面を有する吊橋に対して, 面内荷重を対象とした 弾塑性有限変位解析を実施し, 橋梁全体系の弾塑性挙 動を明らかにする. さらに各構成要素の初期降伏およ び吊橋全体系の終局強度に着目した安全率の組合わせ を検討し，これまでに提案している安全率の組合わせ が有効であるかを明らかにする.

\section{2. 解析モデルと解析方法}

\section{(1) 吊橋モデル}

本解析モデルは, 図-1 に示すような中央径間長 $3000 \mathrm{~m}$ の 3 径間 2 ヒンジ補剛吊橋である ${ }^{5)}$. 塔は, 変 断面を有する 6 層ラーメン形式である. ケーブルは片 側 1 本配置とし, ハンガーの定着間隔は $50 \mathrm{~m}$ である. 補剛桁断面は，桁幅として車線数を 6 車線 (片側 3 車 線) を想定して $35.5 \mathrm{~m}$ とした桁高 $7 \mathrm{~m}$ の単室流線型箱 形である，なお，縦断勾配は考慮していない。 


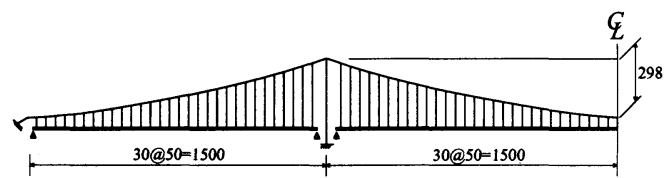

(a) 全体形状

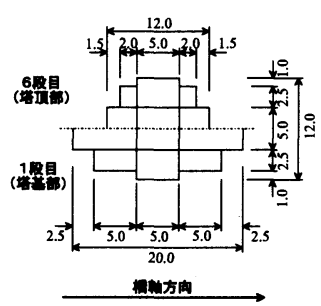

(b) 塔柱断面

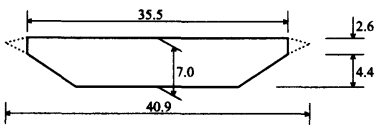

(c) 桁断面

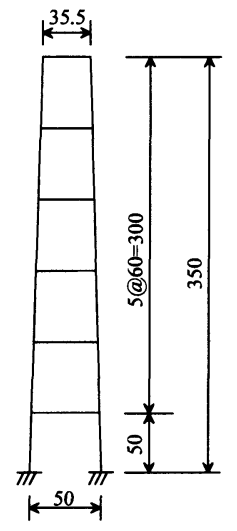

(d) 主塔形状

图-1 吊橋の基本モデル (単位 : m)

衰-1 安全率のパラメータ

\begin{tabular}{lr|l}
\hline \multicolumn{2}{c|}{ 符成要素 } & \multicolumn{1}{c}{ 安 全 率 } \\
\hline \hline 補剛浙 & $\left(\gamma_{G}\right)$ & 1.7 \\
主塔 & $\left(\gamma_{T}\right)$ & $1.7,1.5,1.2$ \\
主ケープル & $\left(\gamma_{C}\right)$ & $2.2,2.0,1.8,1.6,1.4$ \\
ハンカー & $\left(\gamma_{H}\right)$ & $3.0,2.5,2.2,2.0$ \\
\hline
\end{tabular}

明石海峡大橋の安全率 : $\gamma_{T}=1.7, \gamma_{C}=2.2, \gamma_{H}=2.5$

\section{(2) 安全率}

補剛析, 主塔, ケーブルおよびハンガーの安全率は, 表-1 のように変化させる. 表中の補剛析と主塔の安全 率 $\left(\gamma_{G}, \gamma_{T}\right)$ は降伏強度に対する安全率であり, 主ケー ブルとハンガーの安全率 $\left(\gamma_{C}, \gamma_{H}\right)$ は引張強度に対する 安全率である. 参考までに主ケーブルおよびハンガー の安全率は, 降伏強度に対する安全率に換算すると各々 $(1.71,1.55,1.40,1.24,1.08)$ および $(2.26,1.88,1.65$, 1.50) となる. なお, 補剛桁は荷重状態で断面決定され ないため (最小板厚で決まる), 安全率 1.7 を変化させ ていない.

\section{（3）杫成要素の断面镜元と荷量}

補剛析の上, 下フランジ厚は最小板厚相当の $12 \mathrm{~mm}$ とし，縦リブを考虑した換算板厚として $20 \mathrm{~mm}$ を，ウエ ブは縦リブを考虑した換算板厚 $18 \mathrm{~mm}$ を用いた。 その 補剛析断面諸元を表-2 に示す. 補剛析の鋼種はSM400 である.

衰-2 補剛桁および主塔の断面諸元

\begin{tabular}{|c|c|c|c|c|c|}
\hline & $\gamma_{T}$ & $\begin{array}{c}A \\
\left(\mathrm{~m}^{2}\right) \\
\end{array}$ & $\begin{array}{c}I_{x x} \\
\left(\mathrm{~m}^{4}\right)\end{array}$ & $\begin{array}{c}I_{y y} \\
\left(\mathrm{~m}^{4}\right)\end{array}$ & $\begin{array}{c}J \\
\left(\mathrm{~m}^{4}\right)\end{array}$ \\
\hline \multicolumn{2}{|c|}{ 補剛标 } & 1.49 & 14.55 & 181.55 & 26.50 \\
\hline \multirow{6}{*}{ 塔柱 } & \multirow[b]{2}{*}{1.7} & 3.94 & 48.79 & 59.55 & 63.60 \\
\hline & & $\sim 8.30$ & $\sim 105.87$ & $\sim 264.74$ & $\sim 182.20$ \\
\hline & \multirow{2}{*}{1.5} & 3.35 & 29.96 & 36.57 & 39.06 \\
\hline & & $\sim 7.05$ & $\sim 65.02$ & $\sim 162.59$ & $\sim 111.90$ \\
\hline & \multirow{2}{*}{1.2} & 2.76 & 16.74 & 20.43 & 21.81 \\
\hline & & $\sim 5.81$ & $\sim 36.32$ & $\sim 90.81$ & $\sim 62.50$ \\
\hline \multirow{3}{*}{ 塔水平材 } & 下部 & 1.38 & 4.24 & 31.88 & 9.59 \\
\hline & 中間 & 1.50 & 35.63 & 6.88 & 14.29 \\
\hline & 上部 & 1.32 & 21.32 & 5.75 & 10.91 \\
\hline
\end{tabular}

\section{表-3 主ケーブルおよびハンガーの断面諸元}

\begin{tabular}{c|c|c|c}
\hline \multicolumn{2}{c|}{ 主ケーブル } & \multicolumn{2}{|c}{ ハンカー } \\
\hline$\gamma_{C}$ & $A_{C}$ & $\gamma_{H}$ & $A_{H}$ \\
\hline \hline 2.2 & 1.294 & 3.0 & 0.01266 \\
2.0 & 1.085 & 2.5 & 0.01055 \\
1.8 & 0.906 & 2.2 & 0.00928 \\
1.6 & 0.751 & 2.0 & 0.00844 \\
1.4 & 0.616 & \multicolumn{3}{c}{ Unit : $\left(\mathrm{m}^{2} /\right.$ cable $)$}
\end{tabular}

塔柱は, 多室箱型構造であり, 主塔の安全率の変化に 関わらず各層の板厚は, 補剛材を考虑した換算板厚で 一定値を用いている. 各安全率に対応する主塔の塔柱 断面は, 本州四国連絡橋公団の上部構造設計基淮 ${ }^{2}$ に基 づいて設計している. 主塔の各安全率に対応した断面 諸元を表-2 に，また $\gamma_{T}=1.7$ の基本断面形状を图 $-1(\mathrm{~b})$ に示す．塔柱の鋼種は SM570である. なお，主ケーブ ル, ハンガーおよび主塔の安全率の変化に関わらず，主 塔の水平材断面は一定とした. この水平材の断面諸元 を表-2 に示す．水平材の鋼種は SM400 である.

さらに，主ケーブルおよびハンガーの各安全率に対 する断面諸元を表-3に示す. 使用したケーブル材料は 平行線ケーブル ST1770, ハンガーはストランドロープ ST1570である.

補剛析の死荷重強度は, $w_{G}=220.5 \mathrm{kN} / \mathrm{m}$ である. 主 塔の死荷重強度 $w_{T}$ は, 断面積 $A_{T}\left(\mathrm{~m}^{2}\right) \times$ 単位重量 $\gamma_{s}\left(\mathrm{kN} / \mathrm{m}^{3}\right)$ に $40 \%$ 割り増しして算出する.

活荷重は, 本州四国連絡橋公団の上部構造設計基準·同 解説 $\left.{ }^{2}\right)$ に示される等価 $L$ 荷重 $\left(w_{L}=26.46(\mathrm{kN} / \mathrm{m} / \mathrm{Br})\right)$ を用いた. ただし, 活荷重は全長にわたり一定とし, 等 分布荷重を用いることにする. 活荷重の載荷方法には いくつかの考え方があるが，ここでは構造全体系およ び主塔に不利になる代表的荷重条件として, 図-2のよ うな偏載を対象とした. 


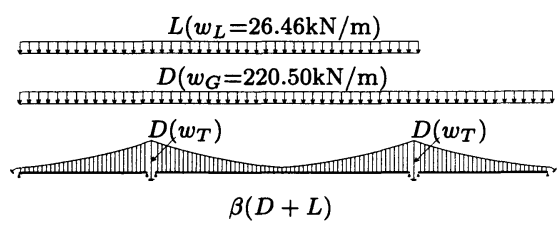

图-2 荷重载荷条件

表-4 材料特性

\begin{tabular}{l|c|c|c|c}
\hline & $\begin{array}{c}\text { 補岡梀 } \\
\text { SM400 }\end{array}$ & $\begin{array}{c}\text { 主塔 } \\
\text { SM570 }\end{array}$ & $\begin{array}{c}\text { 主ケーブル } \\
\text { ST1770 }\end{array}$ & $\begin{array}{c}\text { ヘンガー } \\
\text { ST1570 }\end{array}$ \\
\hline \hline$\sigma_{u}$ & 402 & 568 & 1764 & 1568 \\
$\sigma_{y}$ & 235 & 451 & 1372 & 1176 \\
$E$ & 205800 & 205800 & 196000 & 137200 \\
$E^{\prime} / E$ & 0 & 0 & 0.0364 & 0.0383 \\
$\varepsilon_{y}$ & 0.0011 & 0.0022 & 0.007 & 0.0085 \\
\hline \multicolumn{4}{c}{ Unit : $(\mathrm{MPa})$}
\end{tabular}

\section{（4）終局強度算出法}

数值計算法は, 構成する薄肉断面部材に対して一般に 用いられる基本仮定のもと，幾何学的非線形性に材料非 線形性が加わった複合非線形問題として定式化し, 材料 の応力ーひずみ関係は増分塑性理論による増分法を用 いている. また, この数值計算には, Newton-Raphson 法と組合わせて求める変位増分法を採用する. 解析モ デルの主塔, 補剛标, 主ケーブル及びハンガーに使用し た鋼材の材料特性を表-4 に示す. 表中の $\sigma_{u}$ は引張強 度, $\sigma_{y}, \varepsilon_{y}$ は降伏応力および降伏ひずみ, および $E, E^{\prime}$ はヤング率およびひずみ硬化係数である.

弾塑性有限変位解析における応力ーひずみ関係は, 主 塔および補剛析に対して完全弾塑性型, 主ケーブルお よびハンガーはバイリニア型を仮定した.なお, 鋼種 の変更は行わず全ての安全率に対して同一の鋼材とす る. また, 主塔および補剛桁の局部座屈の影響は考虑 していない.

荷重条件は，まず死荷重 $D$ が作用する初期状態 1.0 (D) を作成する. その後の荷重の載荷方法には死荷重 $D$ と活荷重 $L$ を載荷した状態に対して荷重パラメータ $\beta$ を乗じて荷重 $\beta(D+L)$ を漸增させる方法を採用す る. したがって, $\beta$ に 1 を加えた荷重パラメータを荷 重倍率 $\alpha(=\beta+1)$ と定義する.

\section{(5) 主塔の初期不整}

本論文で着目した主塔の初期たわみは，図-3(a)のよ うに塔頂部において橋軸方向変位 $\delta$ を有する直線形状の 初期たわみとして $\delta=h / 2000$ および $h / 1000$ ( $h$ は塔高) の 2 ケースを対象とする. さらに, 图-3(b) のような塔 柱多室箱型断面 $\left(1 / 4\right.$ 断面) に $\sigma_{r c}=0.1,0.2,0.3,0.4 \sigma_{y}$,

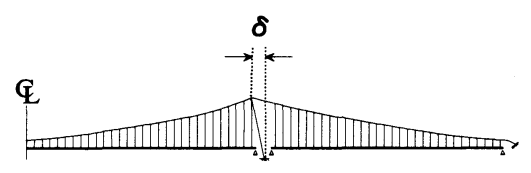

(a) 初期たわみ

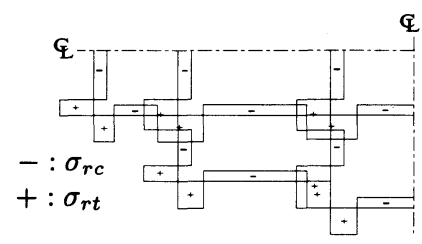

(b) 残留応力分布

图-3 主塔の初期不整

$\sigma_{r t}=1.0 \sigma_{y}$ を有する理想化した溶接型残留応力分布を 4 ケース仮定した. ここに, $\sigma_{r c}, \sigma_{r t}$ は各々圧縮残留応 力および引張残留応力である.

なお，これまでに害測された主塔の圧縮残留応力 $\sigma_{r c}$ は, 板厚 $30 \sim 60 \mathrm{~mm}$ において $0.1 \sigma_{y}$ 以下と非常に小さ いことが報告されている. さらに, 明石海峡大橋の主塔 の場合，その製作精度として主塔の各製作ブロックの 鈆直度は $1 / 10000$ が要求されており, 主塔架設終了後 の検查測定では塔頂での製作・架設の誤差は最大 $39 \mathrm{~mm}$ と非常に高精度で架設されていること，また部材の初 期たわみは最大で部材長の $1 / 1800$, 平均で $1 / 5000$ と 小さいことが確認されている6)。しかし，本研究では 道路橋示方書 ${ }^{1)}$ に規定された柱の基準耐荷力曲線に用 いられている圧縮残留応力 $\sigma_{r c}=0.4 \sigma_{y}$ および部材長の 1/1000 の初期たわみを基本にしてこれまでの実測結果 に比べてより大きな初期不整を採用する，なお, 補剛 桁は初期不整の実測值が小さく7)，また軸圧樎力が小 さいことから，初期不整は考虑していない.

\section{3. 初期不整の終局強度特性への影㬝}

まず，主塔の初期不整として $\delta=h / 2000$ の初期たわ みと $\sigma_{r c}=0.4 \sigma_{y}$ の残留応力を考慮した時の各構成要素 の安全率の変化による弾塑性挙動および全体系の終局 強度への影響, さらに主塔の初期不整を変化させたこ とによる各構成要素および全体系の終局強度への影響 について検討する.

図-4 は, ハンガーの安全率 $\gamma_{H}$ をパラメータにして ケーブルの安全率と終局時の荷重倍率の関係をまとめた ものである. 主塔の安全率が $\gamma_{T}=1.7$ の結果をまとめた 图-4 (a) において, ハンガーの安全率 $\gamma_{H}=3.0$ の荷重 倍率はケーブルの安全率 $\gamma_{C}$ が大きくなるにしたがって 高くなり, $\gamma_{C}=2.2$ の荷重倍率は 3 を超える. $\gamma_{H}=2.5$ では, ケーブルの安全率が $\gamma_{C} \geq 1.8$ になると明石海峡 


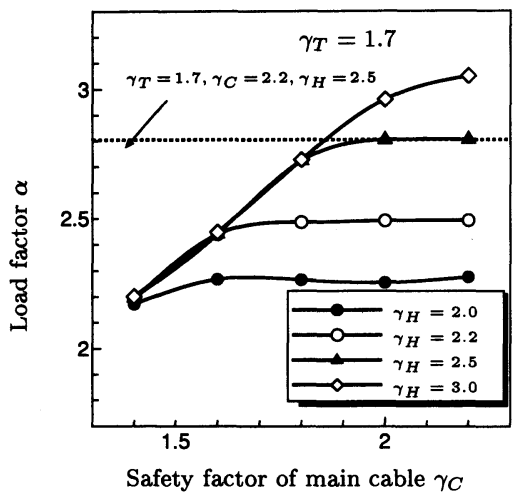

(a) $\gamma_{T}=1.7$

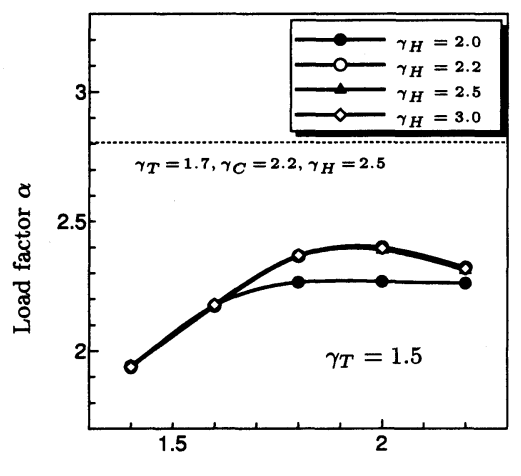

Safety factor of main cable $\gamma_{C}$

(b) $\gamma_{T}=1.5$

图-4 終局時の荷重倍率と安全率の関係

大橋の荷重倍率に漸近している. 一方, $\gamma_{H}=2.2,2.0$ の場合, $\gamma_{C}$ が 1.6 以上になると荷重倍率は変化しない ことから,これらの場合ケーブルの安全率は $\gamma_{C}=1.6$ が合理的となる.

次に, $\gamma_{T}=1.5$ の場合についてまとめたのが図-4 (b) である. ハンガーの安全率が $\gamma_{H}=2.2,2.5,3.0$ と変化 しても荷重倍率とケーブル安全率の関係曲線は一致して いることから， $\gamma_{H}=2.2$ が有効である.この曲線から， ケーブルの安全率はほぼ最大荷重倍率に近い $\gamma_{C}=1.8$ が最も合理的である. さらに, $\gamma_{H}=2.0$ の場合, ケーブ ルの安全率が 1.8 以上では荷重倍率は一定である.ま た, 图-4(a) と (b) の主塔の安全率と荷重倍率の関係を 比較すると, ハンガーの安全率の変化が荷重倍率に与 える影響は $\gamma_{T}=1.5$ の場合の方が $\gamma_{T}=1.7$ の場合に比 べて小さい.

図-5 は, 各構成要素の初期降伏時の荷重倍率と終局 限界時の荷重倍率の関係を示したものである. 図-5 (a) の $\gamma_{T}=1.7, \gamma_{H}=2.5$ において, 明石海峡大橋の安全率 と同じ $\gamma_{T}=1.7, \gamma_{C}=2.2, \gamma_{H}=2.5$ のモデルは, 主塔が $\alpha=1.66$ の荷重倍率で最初に降伏し, ハンガー, 補剛析

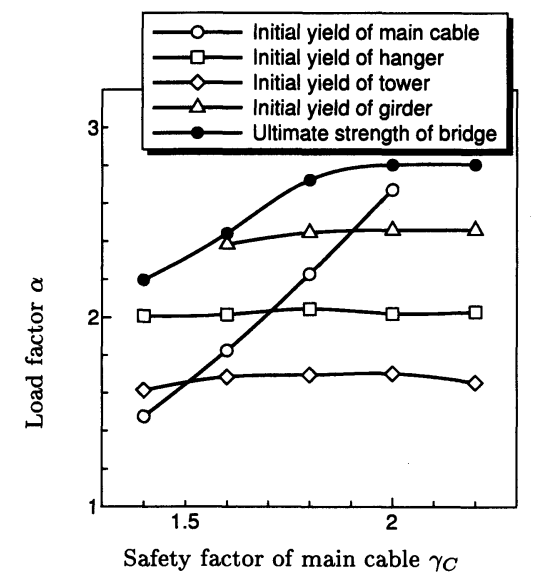

(a) $\gamma_{T}=1.7, \gamma_{H}=2.5$

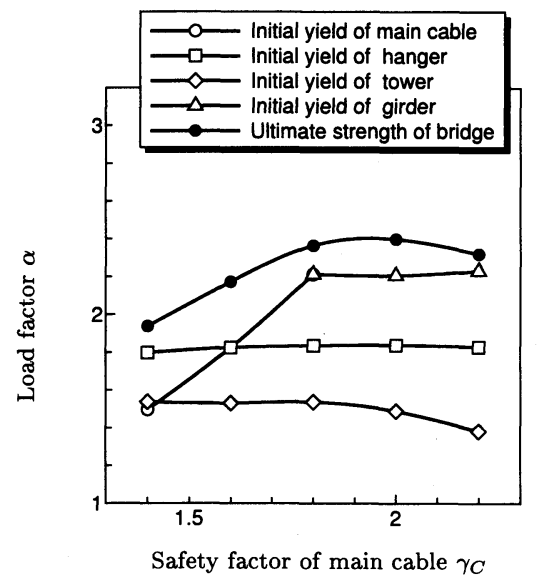

(b) $\gamma_{T}=1.5, \gamma_{H}=2.2$

图-5 構成要素の初期降伏と吊橋の終局強度

と続いたが，主ケーブルに降伏は発生しなかった。 ま た, この時の吊橋の崩壊はハンガーの破断で起こり, そ の時の荷重倍率は $\alpha=2.81$ である. 一方, ケーブル安全 率 $\gamma_{C}$ が 2.0 以下になると, 吊橋の崩壊は構造全体系の 各構成要素の塑性領域の広がりに支配されている. 特 に, $\gamma_{C}=1.8$ の場合, 塔 $\rightarrow$ ハンガー $\rightarrow$ ケーブル $\rightarrow$ 補 剛桁の順に降伏が発生し, 全体系の終局強度は $\gamma_{C}=2.2$ のそれに比べて僅かな低下である.

ところで，主塔の初期不整を無視した明石海峡大橋

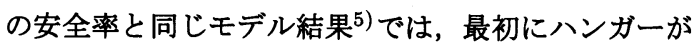
$\alpha=2.13$ で降伏し始め, 主ケーブルと主塔は降伏せず, $\alpha=2.82$ でハンガーの破断により全体系の終局状態を迎 えていたことから，この安全率の組み合わせでは主塔 の初期不整が終局強度に与える影響は小さい.

图-5 (b) は, $\gamma_{T}=1.5, \gamma_{H}=2.2$ に低減した場合で ある. $\gamma_{C}=1.8$ の時, 主塔が $\alpha=1.54$ で初期降伏し, 次 に, ハンガー, 最後にケーブルと主桁が同時に降伏し 
た. 終局時の荷重倍率は $\alpha=2.37$ で全体系の塑性領域 の進展に支配された. ケーブル安全率が $\gamma_{C}=2.2$ の場 合の荷重倍率は, $\gamma_{C}=1.8,2.2$ のそれに比べて低下し ている.これは, ケーブル断面が大きくなることによ り主塔への鉛直反力が増大するため, 主塔の初期降伏 が早まるとともに, 荷重の増大に伴い塑性進展がより 進行するためである.

なお, 同じ安全率の組合わせにおいて主塔の初期不 整を無視した場合, 最初にハンガーが荷重倍率 $\alpha=1.80$ で降伏を始め, 続いて主塔と主ケーブルがほぼ同時に $\alpha=2.19,2.23$ で降伏を開始し, その後各構成要素の塑 性進展により $\alpha=2.48$ において吊橋全体系の終局状態 を迎えた. したがって, 初期不整による吊橋全体系の 終局強度の低下率は $4.4 \%$ である.

以上の結果を踏まえて，代表的な安全率の組合わせ に対して初期不整の有無による初期降伏時および終局 時の荷重倍率およびその増減率をまとめると表 -5 のよ うになる. 表中の $\alpha_{y}, \alpha_{c r}$ は, 各々初期降伏時, および 終局時の荷重倍率を意味する.

图-6 は, $\gamma_{T}=1.5, \gamma_{C}=1.8, \gamma_{H}=2.2$ の安全率の組 合わせモデル $(\delta=h / 2000$ の初期たわみ) における残 留応力の変化が終局強度に与える影響をまとめたもの である．縦軸は残留応力を無視した解析による荷重倍 率 $\alpha_{0}$ に対する残留応力を考虑した場合の荷重倍率 $\alpha$ の 比である. 残留応力の増大に伴い荷重倍率は低下する が，その低下率は最大でも $\sigma_{r c}=0.4 \sigma_{y}$ で $8 \%$ 程度であ る. また, 初期たわみの変化が終局強度に与える影響 については最大の低下率を示した $\delta=h / 1000$ において $1 \%$ 程度であった. したがって，吊橋全体の終局強度へ の主塔の初期不整の影響は小さいことがわかる．ただ し，主塔の初期不整を無視したモデルではハンガーに 最初に降伏が発生したが, 主塔の初期不整を導入した 場合主塔が最初に降伏が発生するなど終局限界に至る 弾塑性挙動が異なる.

\section{4. まとめ}

中央支間長 $3000 \mathrm{~m}$ の 3 径間連続補剛吊橋を対象に弾 塑性有限変位解析を行い, 特に主塔の初期不整が吊橋 全体系の弾塑性崩壊挙動および而荷力へ与える影響を 明らかにするとともに合理的な安全率の組合わせにつ いて検討した.

提案する式(1)の安全率からなる吊橋において, 主塔 の初期不整を考虑することによる初期降伏する構成要 素は, これを無視した場合に比してハンガーから主塔 に変化し, 表-5 からも明らかなようにその荷重倍率も $14.4 \%$ 低くなる. しかし, 吊橋全体系の終局強度に対 するその荷重倍率は $4.4 \%$ の低下であり，さらに 2.(5)
衰-5 初期不整の有無と荷重倍率

\begin{tabular}{|c|c|c|c|c|c|}
\hline \multicolumn{3}{|c|}{ 安全率の組合わせ } & \multirow{2}{*}{ 初期不整 } & \multicolumn{2}{|c|}{ 荷重倍率 } \\
\hline$\gamma_{T}$ & $\gamma_{H}$ & $\gamma_{C}$ & & 降伏時 $\alpha_{y}$ & 終局時 $\alpha_{c r}$ \\
\hline \multirow{3}{*}{1.7} & \multirow{3}{*}{2.5} & 2.2 & 有 & 1.66 & 2.81 \\
\hline & & 1.8 & 有 & 1.65 & 2.72 \\
\hline & & 2.2 & 無 & 2.13 & 2.82 \\
\hline \multirow{2}{*}{1.5} & \multirow{2}{*}{2.2} & \multirow{2}{*}{1.8} & 有 & 1.54 & 2.37 \\
\hline & & & 無 & 1.80 & 2.48 \\
\hline
\end{tabular}

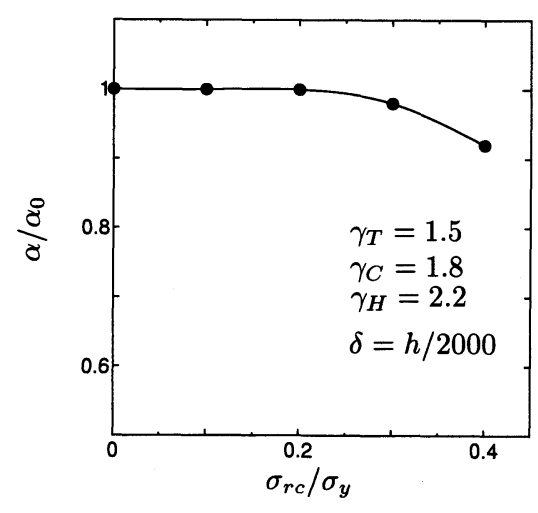

図-6 残留応力の終局強度への影響

で述べたように実橋の初期不整はここで導入した初期 不整より小さいことを考虑するとき, 主塔の初期不整 が吊橋全体系の終局強度に与える影響は小さいことが 明らかである.

また, 解析結果より文献 5) と同様に以下の 3 条件

(1) 最初に降伏し始める要素の初期降伏時の荷重倍率 が，現行の安全率を用いた場合のそれと比較して も同等であること.

(2) 終局状態までに各構成要素が初期降伏を起こし, 吊 橋全体系の塑性進展による崩壊により終局状態を 迎えること.

(3) 吊橋全体系の終局強度は, 所要荷重倍率 $\alpha_{r e q} \approx 2.4$ を確保すること.

を満足する各構成要素の安全率の組合わせとして, 主 塔の初期不整を無視した場合と同様に

$$
\gamma_{T}=1.5, \gamma_{C}=1.8, \gamma_{H}=2.2
$$

を提案することができる.

なお，条件(3の所要荷重倍率については，以下のよ うに解釈できる.いま, 限界状態設計法の書式 ${ }^{9}$ は, 今 回の荷重条件に対して

$$
\gamma_{i} \frac{\sum \gamma_{a} S\left(\gamma_{f} F\right)}{R\left(f / \gamma_{m}\right) / \gamma_{b}} \approx \gamma_{i} \gamma_{b} \gamma_{a} \gamma_{f} \frac{D+L}{R}
$$


と与えられるものとすると，

$$
\alpha_{r e q}=\gamma_{i} \gamma_{b} \gamma_{a} \gamma_{f}
$$

なる関係を得る.ここに, $S, R$ は荷重効果および抵抗 值を表す. $\gamma_{i}, \gamma_{b}, \gamma_{m}, \gamma_{a}, \gamma_{f}$ は各々重要度俰数, 部材 係数, 材料係数, 構造解析俰数および荷重係数である. また, $F, f$ は各々荷重の特性值および強度の特性值で ある.

ところで, 終局限界状態を照查する荷重の組合わせ として $1.3 D+2.2 L$ を考えるとき ${ }^{8}$, 今回対象とした吊 橋の死荷重時と活荷重時作用応力度の比は $\sigma_{D} / \sigma_{L} \approx 9$ となることから

$$
1.3 D+2.2 L=1.39(D+L)=\gamma_{f}(D+L)
$$

の関係より, 荷重係数は $\gamma_{f}=1.39$ となる.もし,これ までに実績のない超長大吊橋の終局強度を算出するた めの解析上の精度のばらつきなどを考虑して構造解析係 数を $\gamma_{a}=1.2$ と仮定し, さらに部材係数を $\gamma_{b}=1.05$ と 置くならば9)，式 (3)にこれらの係数を代入することに より,(3)の所要荷重倍率 $\alpha_{r e q}=2.4$ は重要度俰数として $\gamma_{i}=1.45$ を要求していることと等価である.

謝辞 : 本論文は, 当時東京都立大学大学院工学研究科土 木工学専攻学生であった仲西竜伸君 (大和證券 SMBC) の努力に負うところ大であり，ここに心より感謝する 次第である.

\section{参考文献}

1）日本道路協会 : 鋼道路橋示方書, I 共通編, II 鋼橋編, 丸善, 1993.

2) 本州四国連絡橋公団 : 上部構造設計基準 - 同解説, 1989

3）限界状態設計法による長大吊橋の設計基準の検討委員 会 : 明石海峡大橋主ケーブルに関する検討, 海洋架橋調 査会, 1988 .

4) 海峡横断道路プロジェクト技術調査委員会 : 安全率低减 の検討, 1995 .

5）野上邦栄, 斎藤一則, 長井正呞, 藤野陽三 : 超長大吊 橋の終局強度に着目した主ケーブル，ハンガーおよび 主塔の安全率の合理化, 土木学会論文集, No.549/I-37, pp.55-64, 2001.

6) 山岸一彦, 山田郁夫 : 上部工設計基準類の变䠢, 橋梁と 基砫, Vol.32, No.8, pp.98-102, 1998.

7）大橋治一，依田照彦，捅口康三 : 長大斜張橋銅床版の 初期不整の実測データとその圧縮強度評価, 土木学会論 文集, No.549/I-37, pp.55-64, 1996.

8）野上邦栄, 成田信之 : 吊形式橋梁の塔の座屈設計法に 関する一考察, 土木学会論文集, No.446/I-19, pp.225234, 1992.

9) 鉄道総合技術研究所 : 鉄道構造物等設計標準・同解説 鋼・合成構造物, 1998 .

(2002.2.20 受付)

\title{
EFFECT OF INITIAL IMPERFECTIONS OF TOWERS ON SAFETY FACTORS OF MAIN CABLES, HANGERS AND TOWERS IN A SUPER LONG-SPAN SUSPENSION BRIDGE
}

\author{
Kuniei NOGAMI and Masatsugu NAGAI
}

\begin{abstract}
This paper describes the load carrying capacity of the suspension bridge by considering the initial imperfection of the towers under various combinations of the safety factor of the main cable, hanger and tower. Rational combination of safety factors has to be established by considering both of the initial yielding state of each component and the ultimate state of the bridge. From results of this study, it is presented that the effect of initial imperfection is small, and we propose the combination values of $\gamma_{T}=1.5$, $\gamma_{H}=2.2$, and $\gamma_{C}=1.8$ as the rational safety factor.
\end{abstract}

